\title{
INTERCROPPING MAIZE WITH DIFFERENT VEGETABLES
}

\author{
M. R. Ali ${ }^{1}$, M. S. Rahman ${ }^{2}$, M. Asaduzzaman ${ }^{1}$, M. M. Hossain ${ }^{1}$ and M. A. Mannan ${ }^{3}$ \\ ${ }^{1}$ Senior Scientific Officer, Regional Agricultural Research Station, BARI, Jamalpur, \\ ${ }^{2}$ Upazila Agriculture Officer, DAE, Gopalpur, Tangail, \\ ${ }^{3}$ Principal Scientific Officer, Regional Agricultural Research Station, BARI, Jamalpur
}

Key words: Intercropping, maize, vegetable, equivalent yield, economics

\begin{abstract}
An intercropping experiment was conducted in the farmer's field at Farming Systems Research and Development (FSRD) Site, Kushumhati, Sherpur in sandy loam soil of medium high land during rabi season 2011-12 to observe the productivity and economic feasibility of intercropping systems as compare $3 \mathrm{~d}$ to sole crop (viz. maize + potato, maize + Radish, maize-+-coriander, maize + bushbean, maize + spinach, maize + lalshak and maize sole). The result indicated that grain yield of maize was reduced due to intercropping systems but this reduction was compensated by intercropped. The highest grain yield of maize was found from sole maize (10.90 t ha-1) and lowest $(9.32$ $\mathrm{t} \mathrm{ha}^{-1}$ ) from intercropped with potato. The maximum maize equivalent yield (14.04 t ha $^{-1}$ ), gross return (Tk.10,5300/ha),gross margin (Tk. 75,527/ ha),, and benefit cost ratio (BCR) (3.54) was obtained from maize + bushbean intercropping systems which was adventitious over sole maize cropping.
\end{abstract}

\section{Introduction}

Maize is one of the most important cereal crops in the world both as food for human and feed for animals. It is the most efficient crop which can give high biological yield as well as grain yield relatively in a shorter period of time due to its unique photosynthetic mechanism as $\mathrm{C} 4$ plant (Hatch and Slack, 1996). In Bangladesh, the cultivable land is declining day by day. So, the production of food grain could be increased by adopting intercropping system. Intercropping is the practice of growing two or more crop together in the same piece of land in stipulated time, particularly in the tropics. The vegetable production could be increased through intercropping practices as the horizontal expansion of area is limited. Maize as wider spaced plant offers some component crops to grow together without economic loss sacrificing small maize yield with greater total production in respect of land and time. This practice offered considerable yield advantages and higher economic return over sole intercropping because of its efficient utilization of growth resources (Faruque et al., 1996). The results of intercropping maize with legumes and vegetables is a profitable system as reported by Uddin and Satter (1993). Moreover, little information is available for suitable intercrop combination of vegetables with maize. Considering the above facts, the experiment was undertaken to find out the suitable intercropping system of vegetables with maize for increasing total productivity, return and maximize land utilization.

\section{Materials and Methods}

The experiment was conducted at the Farming System Research and Development (FSRD) site, Kushumhati, Sherpur during the rabi season 2011-12. The soil was sandy loam of Old Brahmaputra Floodplain under AEZ 9. The experiment consisted of seven treatmernts, viz. i) 
Ali et al.

maize + potato ii) maize + radish iii) maize + coriander iv) maize + bushbean v) maize + spinach vi) maize + lalshak and vii) maize sole. The treatments were tested in randomized complete block design with 3 replications. The unit plot size was $4.5 \mathrm{~m} \times 5 \mathrm{~m}$. The variety Pacific 11, Dhira, Druti, Local, BARI Jharsheem 1, Local and BARI Lalsak 1 were used for maize, potato, radish, coriander, bushbean, spinach and lalsak, respectively. All vegetables were sown in lines in between the maize rows maintaining the standard spacing of the respective vegetables. Maize seeds were sown in a planting configuration of $75 \mathrm{~cm} \times 25 \mathrm{~cm}$ spacing and fertilized at the rate of 256-55-138-3-1 kg ha-1 of NPKSB and cow dung at the rate of $5 \mathrm{tha}^{-1}$. Full amount of PKSB, 2/3 rd of $\mathrm{N}$ and $12 \mathrm{~kg} \mathrm{ha}^{-1}$ (furadan) along with full amount of cow dung were applied at the time of final and preparation. The rest $\mathrm{N}$ was applied into two equal splits at 8-10 leaves stage and at tasselling stage. Seeds of maize and all other vegetables were sown on November 28, 2011. Intercropped vegetables were harvested depending on the maturity of the individual crops ranging from December 28, 2011 to February 6, 2012 and maize was harvested on April 19, 2012. Intercultural operation was done as and when necessary. Grain yield of maize was determined at $14 \%$ moisture content. Equivalent yield of component crops were determined following the method of

Anjaneyulu et al. (1982).

Maize Equivalent Yield (MEY) $=\mathrm{Ym}+\frac{Y i \times P i}{P m}$

Where,

$$
\begin{aligned}
& \mathrm{Ym}=\text { Yield of maize }\left(\mathrm{t} \mathrm{ha}^{-1}\right) \\
& \mathrm{Yi}=\text { Yield of intercrop vegetable }\left(\mathrm{t} \mathrm{ha}^{-1}\right) \\
& \mathrm{Pi}=\text { Price of intercrop vegetables }\left(\mathrm{Tk} \mathrm{ha}^{-1}\right) \\
& \left.\mathrm{Pm}=\text { Price of maize }(\mathrm{Tk} \mathrm{ha})^{-1}\right)
\end{aligned}
$$

Data recorded on the different parameters were analysed and means were separated following DMRT test at $5 \%$ level of significance.

\section{Results and Discussion}

The result indicated that most of the yield attributes were significantly influenced due to maize vegetable intercropping but cobs/plant and 1000-grain weight was found insignificant (Table 1). The highest grains/cob (458.6) was achieved from sole maize and it was statistically similar to other treatments except maize + potato and maize + radish treatments which produced the lowest grains/cob (415.3) The maximum grain yield (10.90 $\mathrm{t} \mathrm{ha}^{-1}$ ) was recorded from sole maize and it was statistically identical to all other treatments except maize + potato $\left(9.70 \mathrm{t} \mathrm{ha}^{-1}\right)$ and maize + radish (9.92 $\mathrm{t} \mathrm{ha}^{-1}$ ). OFRD (2006) and Bhuiyan et al., 1999 also reported that sole maize gave the highest yield among the treatments. All the treatments showed similar straw yield except maize + radish which gave the lowest yield $\left(4.87 \mathrm{t} \mathrm{ha}^{-1}\right)$. The highest maize equivalent yield (14.04 $\mathrm{t} \mathrm{ha}^{-1}$ ) was produced by maize + bushbean treatment (Table 3). The result confirms the findings of Bhuiyan et al. (1999). Other treatment showed lower maize equivalent yield of $11.32,11.06,10.81$ and $10.66 \mathrm{t} \mathrm{ha}^{-1}$ from maize + spinach, maize + lalshak, maize + radish and maize + coriander, respectively. The lowest maize equivalent yield (10.16 $\left.\mathrm{t} \mathrm{ha}^{-1}\right)$ was noticed from maize + potato treatment. The highest gross return was found from maize + bushbean intercropping (Tk.1,05,300/ha while the lowest gross return (Tk. $76,200 \mathrm{ha}^{-1}$ ) was recorded from maize + potato combination. The total cost was found highest (Tk. $42523 \mathrm{ha}^{-1}$ ) in maize + potato treatment due to higher seed cost of potato (Table 2). The lowest total cost was found from maize sole treatment. However, the highest benefit cost ratio was found in maize + bushbean intercropping system (3.54) and the lowest benefit cost ratio from maize + potato intercropping. Santalla et al. (2001) was also found that greatest net 
Intercropping Maize with Different Vegetables

income from bushbean intercropped with sweet maize. All the intercropping system other than maize + bushbean failed to show higher benefit than sole maize.

\section{Conclusion}

From the above result showed that maize intercropping with bushbean was found agronomically viable and economically profitable than sole crop of maize but other intercropping combinations failed to show higher benefit.

Table 1. Yield attributes and grain yield of maize in different maize + vegetable intercropping Systems

\begin{tabular}{|c|c|c|c|c|c|c|}
\hline \multirow[t]{2}{*}{ Intercropping system } & \multirow{2}{*}{$\begin{array}{c}\text { Cobs/ } \\
\text { plant (no.) }\end{array}$} & \multirow{2}{*}{$\begin{array}{l}\text { Grains/ } \\
\text { cob (no.) }\end{array}$} & \multirow{2}{*}{$\begin{array}{c}1000- \\
\text { grain } \\
\text { weight }(\mathrm{g})\end{array}$} & \multicolumn{2}{|c|}{ Yield ( $\left.\mathrm{tha}^{-1}\right)$} & \multirow{2}{*}{$\begin{array}{c}\text { Stover } \\
\text { yield } \\
\left(\mathrm{t} \mathrm{ha}^{-1}\right)\end{array}$} \\
\hline & & & & Maize & Intercrop & \\
\hline Maize + Potato & 1.10 & $415.3 \mathrm{~b}$ & 320.33 & $9.70 \mathrm{~b}$ & 10.08 & $5.50 \mathrm{ab}$ \\
\hline Maize + Radish & 1.06 & $427.9 \mathrm{~b}$ & 320.00 & $9.92 b$ & 8.12 & $4.87 \mathrm{~b}$ \\
\hline Maize + Coriander & 1.06 & $451.4 \mathrm{a}$ & 320.33 & $10.54 \mathrm{a}$ & 0.64 & $5.62 \mathrm{ab}$ \\
\hline Maize + Bushbean & 1.06 & $453.3 \mathrm{a}$ & 320.67 & $10.57 \mathrm{a}$ & 6.27 & $5.73 \mathrm{ab}$ \\
\hline Maize + Spinach & 1.11 & $450.7 \mathrm{a}$ & 320.00 & $10.50 \mathrm{a}$ & 5.08 & $5.54 \mathrm{ab}$ \\
\hline Maize + Lalshak & 1.30 & $447.2 \mathrm{a}$ & 320.33 & $10.49 \mathrm{a}$ & 3.31 & $6.03 \mathrm{a}$ \\
\hline Maize sole & 1.08 & $458.3 \mathrm{a}$ & 330.00 & $10.90 \mathrm{a}$ & - & $6.37 \mathrm{a}$ \\
\hline CV (\%) & 3.67 & 5.99 & 1.43 & 5.39 & - & 8.96 \\
\hline
\end{tabular}

Figure in the column having similar letter (s) do not differ significantly by DMRT Test

Table 2. Total cost involved in maize+vegetables intercropping systems

\begin{tabular}{l|c|c|c|c}
\hline Intercropping system & $\begin{array}{c}\text { Cost of fertilizer, } \\
\text { irrigaion and labour } \\
(\text { Tk. ha-1) }\end{array}$ & $\begin{array}{c}\text { Seed cost } \\
\text { (Tk. / ha) }\end{array}$ & $\begin{array}{c}\text { Additional } \\
\left.\text { cost (Tk. ha }{ }^{-1}\right)\end{array}$ & $\begin{array}{c}\text { Total cost } \\
\left.\text { (Tk. ha }{ }^{-1}\right)\end{array}$ \\
\hline Maize + Potato & 26557.00 & 13166.00 & 2800.00 & $42,523.00$ \\
Maize + Radish & 26557.00 & 1766.00 & 1050.00 & $29,373.00$ \\
Maize + Coriander & 26557.00 & 2766.00 & 1750.00 & $31,073.00$ \\
Maize + Bushbean & 26557.00 & 2166.00 & 1050.00 & $29,773.00$ \\
Maize + Spinach & 26557.00 & 3566.00 & 1050.00 & $31,173.00$ \\
Maize + Lalshak & 26557.00 & 1366.00 & 1050.00 & $28,973.00$ \\
Sole maize & 24632.00 & 1166.00 & - & $25,798.00$ \\
\hline
\end{tabular}

Table 3. Agronomic productivity and economics of maize-vegetables intercropping systems

\begin{tabular}{|c|c|c|c|c|c|}
\hline Intercropping system & $\begin{array}{c}\text { Maize } \\
\text { equivalent } \\
\text { yield (t ha-1) }\end{array}$ & $\begin{array}{c}\text { Gross } \\
\text { return (Tk. } \\
\text { ha-1) }^{-1}\end{array}$ & $\begin{array}{l}\text { Total cost } \\
(\text { Tk. ha-1) }\end{array}$ & $\begin{array}{c}\text { Gross margin } \\
\left(\mathrm{Tk} . \mathrm{ha}^{-1}\right)\end{array}$ & $\begin{array}{c}\text { Benefit cost } \\
\text { ratio }\end{array}$ \\
\hline Maize + Potato & 10.16 & 76200 & 42523 & 33677 & 1.79 \\
\hline Maize + Radish & 10.81 & 81075 & 29373 & 51702 & 2.76 \\
\hline Maize + Coriander & 10.66 & 79950 & 31073 & 48877 & 2.57 \\
\hline Maize + Bushbean & 14.04 & 105300 & 29773 & 75527 & 3.54 \\
\hline Maize + Spinach & 11.32 & 84900 & 31173 & 53727 & 2.72 \\
\hline Maize + Lalshak & 11.06 & 82950 & 28973 & 53977 & 2.86 \\
\hline Sole maize & 10.90 & 81750 & 25,798 & 55952 & 3.17 \\
\hline
\end{tabular}

Seed price/kg: Potato=Tk.15.00, Radish=Tk.200.00, Bushbean=Tk.50.00, Lalshak= Tk.500.00,

Spinach $=$ Tk.30.00, Coriander $=$ Tk. 40.00, Maize $=$ Tk. 106.00.Sell price $/ \mathrm{kg}$ : Potato=Tk.4.00, Radish= Tk.1.00, Bushbean=Tk.7.00, Lalshak= Tk.3.00,

Spinach $=$ Tk.2.50, Coriander $=$ Tk. 15.00, Maize $=$ Tk. 7.50 
Ali et al.

\section{References}

Anjaneyulu, V.R., S.P. Singh and M. Pal. 1982. Effect of competition free period and technique and pattern of pearlmillet planting on growth and yield of mungbean and total productivity in solid pearlmillet/mungbean intercropping system. Indian J. Agron. 27: 219-226.

Bhuiyan, M. K. A., M. M. Haque, Q. A. Khaliq, J. A. Begum and A. H. M. R. Mawlla. 1999. Productivity and economics of grain legumes intercropped with maize. Bangladesh Agron. J. 9 (1\&2): 35-42.

Faruque. A., A. Hashem and A. Jahan. 1996. Productivity and profitability of potato intercropped with wheat. Bangladesh J. Bot. 25(1): 1-4.

Hatch, M.D. and C.R. Slack. 1996. Photosynthesis by sugarcane leaves. A new carboxylation reaction and pathway of sugar formation. Biochem. J. 101(7): 103.

On-Farm Research Division (OFRD), Bangladesh Agricultural Research Institute, Joydebpur, Gazipur. 2006. Intercropping maize with short duration vegetables crop. Annual Research Report. pp 291-297.

Santalla, M., A. P. Rodino, P. A. Casquero and A. M. Ron. 2001. Interactions of bush bean with field and sweet maize. European J. Agron. 15 (3): 185-196.

Uddin, M. S. and M. A. Satter. 1993. Prospects of intercropping maize with legumes and vegetables in hill tracts. Bangladesh J. Agril. Res. 18(2): 227-230. 